\title{
Influence of Gliricidia sepium Biochar on Attenuate Perchlorate-Induced Heavy Metal Release in Serpentine Soil
}

\author{
Prasanna Kumarathilaka and Meththika Vithanage \\ Chemical and Environmental Systems Modeling Research Group, National Institute of Fundamental Studies, Kandy, Sri Lanka \\ Correspondence should be addressed to Meththika Vithanage; meththikavithanage@gmail.com
}

Received 10 September 2016; Revised 6 December 2016; Accepted 20 December 2016; Published 14 February 2017

Academic Editor: Ana Moldes

Copyright (c) 2017 Prasanna Kumarathilaka and Meththika Vithanage. This is an open access article distributed under the Creative Commons Attribution License, which permits unrestricted use, distribution, and reproduction in any medium, provided the original work is properly cited.

\begin{abstract}
Perchlorate $\left(\mathrm{ClO}_{4}^{-}\right)$is a strong oxidizer, capable of accelerating heavy metal release into regolith/soil. Here, we assessed interactions between $\mathrm{ClO}_{4}{ }^{-}$and serpentine soil to simulate and understand the fate of $\mathrm{Ni}$ and $\mathrm{Mn}$ and their immobilization with the presence of biochar (BC). A soil incubation study (6 months) was performed using serpentine soil in combination with different $\mathrm{ClO}_{4}{ }^{-}$ concentrations $(0.25,0.5,0.75$, and $1 \mathrm{wt} . \%)$ and three different amendment rates (1, 2.5, and $5 \mathrm{wt} . \%)$ of Gliricidia sepium BC. Bioavailable fraction of $\mathrm{Ni}$ and $\mathrm{Mn}$ was analyzed using $\mathrm{CaCl}_{2}$ extraction method. An increase of $\mathrm{ClO}_{4}{ }^{-}$concentrations enhanced bioavailability fraction of $\mathrm{Ni}$ and $\mathrm{Mn}$. However, $\mathrm{BC}$ amendments reduced the bioavailability of $\mathrm{Ni}$ and $\mathrm{Mn}$. In comparison, 5\% $\mathrm{BC}$ amendment significantly immobilized the bioavailability of $\mathrm{Ni}(68-92 \%)$ and $\mathrm{Mn}$ (76-93\%) compared to other BC amendment rates. Electrostatic attractions and surface diffusion could be postulated for $\mathrm{Ni}$ and $\mathrm{Mn}$ immobilization by $\mathrm{BC}$. In addition, $\mathrm{ClO}_{4}{ }^{-}$ may have adsorbed to $\mathrm{BC}$ via hydrogen bonding which may reduce the influence of $\mathrm{ClO}_{4}{ }^{-}$on $\mathrm{Ni}$ and $\mathrm{Mn}$ mobility. Overall, it is obvious that $\mathrm{BC}$ could be utilized as an effective amendment to immobilize $\mathrm{Ni}$ and $\mathrm{Mn}$ in heavy metal and $\mathrm{ClO}_{4}{ }^{-}$contaminated soil.
\end{abstract}

\section{Introduction}

Perchlorate is an inorganic anion and strong oxidizer and can contaminate water and soil due to the dissolution of solid salts of ammonium $\left(\mathrm{NH}_{4}^{+}\right)$, potassium $\left(\mathrm{K}^{+}\right)$, magnesium $\left(\mathrm{Mg}^{2+}\right)$, and sodium $\left(\mathrm{Na}^{+}\right)$perchlorate and perchloric acid $\left(\mathrm{HClO}_{4}\right)$ in water $[1,2]$. A wide variety of anthropogenic activities (i.e., fireworks, explosives, stick matches, highway safety flares, and military operations) lead to contamination of $\mathrm{ClO}_{4}{ }^{-}$in soil system [3]. In this sense, the presence of $\mathrm{ClO}_{4}{ }^{-}$in soil may aid in accelerated mineral dissolution, therefore, increasing heavy metal release potential into the soil and groundwater. It has been experimentally observed that the rate of dissolution of minerals increases with the addition of perchloric acid in ulexite which is considered as one of the most common boron-containing minerals [4]. In addition, Senanayake et al. [5] examined the dissolution of $\mathrm{Ni}$ and $\mathrm{Co}$ in the presence of perchloric acid in laterite. Moreover, Majima et al. [6] investigated dissolution of $\mathrm{Fe}$ in goethite and hematite in the presence of perchloric acid. Therefore, the interaction between $\mathrm{ClO}_{4}{ }^{-}$and heavy metal contaminated sites may tend to dissolve heavy metals, and, consequently, it could be a possible pathway for leaching metals to the water bodies and, eventually, accumulate in living organisms through the food chain [7].

Heavy metals continue to pose environmental contamination worldwide (i.e., naturally contaminated soils, industrially contaminated urban soils, shooting ranges, and mining sites) [8-11]. Rajapaksha et al. [8] demonstrated that $\mathrm{Ni}$ and $\mathrm{Mn}$ have been released from the serpentine soil in Ussangoda in Sri Lanka at rates of $1.55 \times 10^{-13}$ and $7.89 \times$ $10^{-14} \mathrm{~mol} \mathrm{~m}^{-2} \mathrm{~s}^{-1}$, respectively, with the presence of inorganic (sulfuric, nitric, and hydrochloric) and organic (citric, acetic, and oxalic) acids. In addition, Vithanage et al. [12] examined four serpentinite bodies in Sri Lanka in order to assess the bioavailability fraction and the results revealed that bioavailability fraction of $\mathrm{Ni}$ and $\mathrm{Mn}$ was ranged between 33 to $323 \mathrm{mg} \mathrm{kg}^{-1}$ and 11 to $76 \mathrm{mg} \mathrm{kg}^{-1}$, respectively. Different kinds of techniques (i.e., subsurface barriers, chemical treatment, phytoremediation, and soil washing) have been introduced 
and proposed to remediate heavy metal contaminated soils and they could change the chemistry of the soil media which may reduce the mobility and bioavailability of heavy metals. In this context, $\mathrm{BC}$ is recognized to be an effective adsorbent for heavy metals [13].

Biochar is produced through the thermochemical process of biomass under oxygen limited conditions [14,15]. Different types of biomass such as forestry and agricultural crop residues, invasive plant species, wood waste, animal manures, and organic portion of municipal solid waste have been used as feedstock for producing BC [16-19]. However, pyrolysis conditions, together with feedstock characteristics, mainly govern the physical and chemical properties of the resulting BC [13]. Furthermore, application of BC to soil system has shown a significant importance possibly due to its ability to improve soil nutrient content and water holding capacity as well as carbon sequestration, therefore minimizing greenhouse gas emissions [20-22].

Biochar amendments onto contaminated soils would greatly reduce the total metal concentration and bioavailability fraction [23-26]. For instance, Ahmad et al. [27] found that soybean stover-derived BC more efficiently immobilized $\mathrm{Pb}(88 \%)$ and $\mathrm{Cu}(87 \%)$ in shooting range soil in Cheorwon-gun in Gangwon-do, Korea. In another study, the sequential extraction results in a long-term (three years) field experiment reported that BC amendment (0.5-2\%) increased the residue fractions of $\mathrm{Ni}(\mathrm{II})$ (from $51 \%$ to $61-66 \%$ ) and $\mathrm{Zn}$ (II) (from 7\% to 27-35\%) [28]. Possibly due to the high porous microstructure, $\mathrm{pH}$, active functional groups, surface area, and cation exchange capacity, BC may immobilize heavy metals through different processes (i.e., adsorption, ion exchange, precipitation, and surface complexation) $[29,30]$. Hence, we hypothesized that $\mathrm{BC}$ may be a possible material to be used in the attenuation of heavy metals in $\mathrm{ClO}_{4}{ }^{-}$ contaminated soil. In this study, the serpentine soil was used as a model soil due to the high heavy metal concentrations and bioavailability $[12,31]$. Although it has been observed that the $\mathrm{ClO}_{4}{ }^{-}$addition may increase the heavy metal release and enhance leaching, no studies have focused their attention on immobilizing the metals released due to $\mathrm{ClO}_{4}{ }^{-}$. Therefore, this study assessed the effectiveness of BCs derived from Gliricidia sepium biomass on the $\mathrm{Ni}$ and $\mathrm{Mn}$ immobilization in a serpentine soil with the presence of $\mathrm{ClO}_{4}{ }^{-}$.

\section{Experimental Section}

2.1. Soil Collection and Characterization. Serpentine soil, obtained from Yudhaganawa (latitude $7^{\circ} 71^{\prime} 67^{\prime \prime} \mathrm{N}$ and longitude $80^{\circ} 93^{\prime} 33^{\prime \prime} \mathrm{E}$ ), Sri Lanka, was used for this study. The soil was collected from 0 to $15 \mathrm{~cm}$ below the surface, airdried, and mechanically sieved to $<2 \mathrm{~mm}$ fraction.

The total heavy metal concentrations in serpentine soil was analyzed by completely dissolving the sample in a closed vessel device using temperature controlled microwave heating system (Mars 6, CEM Corporation) with a mixture of hot, concentrated $\mathrm{HNO}_{3}$ and $\mathrm{HCl}$.

2.2. Biochar Production and Characterization. Biochar was collected as a waste byproduct from a bioenergy industry at
Thirappane, north central province, Sri Lanka, where biomass of Gliricidia sepium was gasified to produce electricity. The reactor temperature of this process is maintained at $900^{\circ} \mathrm{C}$ and the limited air is used for the gasification. The obtained BC was air-dried and ground to less than $1 \mathrm{~mm}$ before use. The characteristics such as $\mathrm{pH}$ and electrical conductivity (EC) were measured in 1:5 suspensions of BC-to-water using a digital pH meter (702SM Titrino, Metrohm) and electrical conductivity meter (Orion 5-Star Meter, Thermo Scientific), respectively. Proximate analysis was conducted based on the experimental procedure given in Ahmad et al. [32]. Elemental compositions, BET surface area, pore volume, and pore size of Gliricidia sepium BC were obtained from our previous study [23].

Spectral characteristics of bare Gliricidia sepium BC and $\mathrm{ClO}_{4}{ }^{-}$adsorbed $\mathrm{BC}$, which was obtained reacting $1 \% \mathrm{ClO}_{4}{ }^{-}$ solution and Gliricidia sepium BC $(2.5 \mathrm{w} / \mathrm{v})$ for $3 \mathrm{~h}$ at room temperature $\left(\sim 30^{\circ} \mathrm{C}\right)$, were analyzed by Fourier Transform Infrared (FTIR) Spectroscopy (Nicolet 6700, USA). A wavelength range of $500-4000 \mathrm{~cm}^{-1}$ was used to obtain FTIR spectra with 128 scans at a resolution of $6 \mathrm{~cm}^{-1}$. Sample pellets were prepared for FTIR by mixing $4 \mathrm{mg}$ of samples with fused $100 \mathrm{mg}$ of $\mathrm{KBr}$. Spectral analyses were performed using OMNIC (version 8.0) software tools (Nicolet 6700, USA).

2.3. Soil Amendments and Incubation Experiment. An incubation experiment was performed for serpentine soil with adding different $\mathrm{ClO}_{4}{ }^{-}$concentrations $(1,0.75$, and $0.5 \mathrm{w} / \mathrm{w})$ by using $\mathrm{HClO}_{4}$ acid (AR, BDH, 70\%) and different $\mathrm{BC}$ amendment rates $(1,2.5$, and $5 \mathrm{w} / \mathrm{w})$. In addition, controls (without BC) were used for purposes of comparison. To ensure homogeneous distribution of $\mathrm{ClO}_{4}{ }^{-}$, soil samples were mixed thoroughly after the addition of $\mathrm{ClO}_{4}{ }^{-}$. Serpentine soil (100 g) was placed in polypropylene bottles, and perchloric acid was added with three different concentrations mentioned above. In addition, water was added to $\sim 70 \%$ of water holding a capacity of the soil and then allowed for the incubation in airtight condition at room temperature $\left(\sim 30^{\circ} \mathrm{C}\right)$ for 6 months. Each treatment was performed in triplicate. After 6-month incubation period, single extraction $\left(\mathrm{CaCl}_{2}\right.$ extraction) was performed to evaluate the bioavailability of $\mathrm{Ni}$ and $\mathrm{Mn}$. Serpentine sediment $(1 \mathrm{~g})$ was extracted with $10 \mathrm{~mL}$ of $0.01 \mathrm{M} \mathrm{CaCl}_{2}$. The solid solution was stirred for $2 \mathrm{~h}$. The soil solution was centrifuged, filtered through membrane filtration $(0.45 \mu \mathrm{m})$, and analyzed for $\mathrm{Ni}$ and $\mathrm{Mn}$ using Atomic Absorption Spectrometry (AAS-Model GBC 933 AA).

2.4. Statistical Analysis. Statistical analysis was performed to compare how different $\mathrm{BC}$ amendment rates influence the immobility of $\mathrm{Ni}$ and $\mathrm{Mn}$ in serpentine soil. All results were expressed as the mean values. Data were analyzed by using one-way analysis of variance (ANOVA). The mean separation was done using Duncan's Multiple Range Test (DMRT) (at $P=0.05$ ). The Pearson correlation coefficient is used to measure the strength of linear associations. All statistical analyses were carried out using SAS statistical software package (SAS 9.1). 


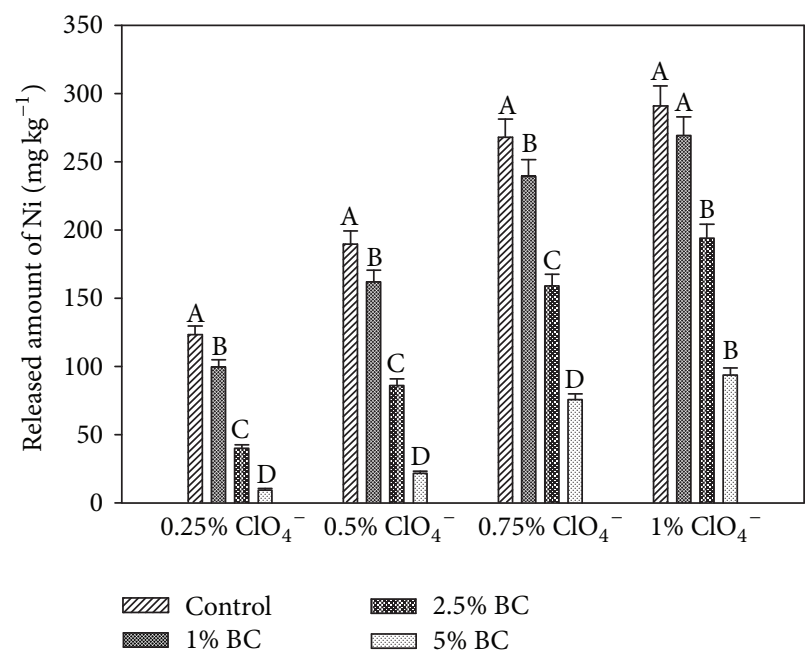

(a)

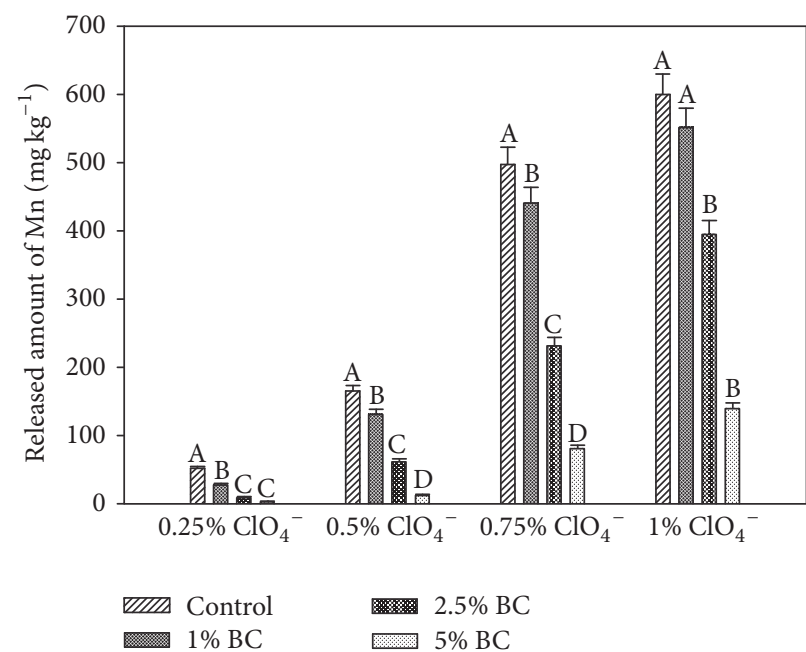

(b)

FIGURE 1: Effect of different rates of BC amendments on bioavailability of heavy metals, (a) Ni and (b) Mn. Letters (A, B, C, and D) within a single graph indicate whether the means significantly differ from each other. Means topped with the different letter differ significantly $(p=0.05)$ and vise versa.

\section{Results and Discussion}

3.1. Biochar and Soil Characteristics. Characteristics of the Gliricidia sepium BC are summarized in Table 1. The data demonstrate that fixed carbon amount of Gliricidia sepium $\mathrm{BC}$ is higher than that of mobile matter indicating loss of volatile matter during the thermal decomposition. It is known that mobile and fixed carbon in BCs are prevailing factors in terms of short-term and long-term availabilities of carbon in soil system [27]. The relatively high amount of ash content indicated the accumulation of inorganic minerals as well as organic matter combustion residue [33]. The high BET surface areas in Gliricidia sepium BC could be attributed to the developments of mesopores, as indicated by their pore sizes of $4.08 \mathrm{~nm}$. Atomic $\mathrm{H} / \mathrm{C}$ and $\mathrm{O} / \mathrm{C}$ ratios are an index of aromaticity and carbonization. Comparatively, a low ratio of $\mathrm{H} / \mathrm{C}$ and $\mathrm{O} / \mathrm{C}$ is possibly due to the dehydration, decarboxylation, and decarbonylation of Gliricidia sepium biomass [34].

It is obvious that soil $\mathrm{pH}$ significantly affects the mobility of metals [35]. Typically, BC is alkaline in nature and, therefore, it would play a major role for immobilization of metals on one hand and mobilization of oxyanions on the other hand. In addition, owing to the liming effect of $\mathrm{BC}$ in soil, BC could affect the sorption of metals. According to Table 2, it clearly shows that soil $\mathrm{pH}$ has increased gradually with increasing $\mathrm{BC}$ amendment rates. However, soil $\mathrm{pH}$ dropped slightly when increasing $\mathrm{ClO}_{4}{ }^{-}$concentrations in serpentine soils.

Furthermore, it appeared that serpentine soil contains a high concentration of $\mathrm{Ni}$ and $\mathrm{Mn}$ (Table 3 ). In addition, bioavailable fractions of $\mathrm{Ni}$ and $\mathrm{Mn}$ were 0.30 and $0.25 \%$ of total $\mathrm{Ni}$ and $\mathrm{Mn}$ in serpentine soil.

3.2. Release of Heavy Metals at $\mathrm{ClO}_{4}{ }^{-}$Addition. With the addition of $\mathrm{ClO}_{4}{ }^{-}$concentrations, $\mathrm{CaCl}_{2}$ extracted $\mathrm{Ni}$ and
$\mathrm{Mn}$ were readily increased. For instance, $0.25 \% \mathrm{ClO}_{4}{ }^{-}$addition mobilized 123 and $52 \mathrm{mg} \mathrm{kg}^{-1}$ of $\mathrm{Ni}$ and $\mathrm{Mn}$, respectively, after 6-month incubation period. In comparison, $1 \% \mathrm{ClO}_{4}{ }^{-}$ addition mobilized 291 and $600 \mathrm{mg} \mathrm{kg}^{-1}$ of $\mathrm{Ni}$ and $\mathrm{Mn}$, respectively, and this figure corresponded to 4.43 and $22.99 \%$ of total $\mathrm{Ni}$ and $\mathrm{Mn}$ concentrations, respectively. In addition, when increasing $\mathrm{ClO}_{4}{ }^{-}$concentrations from 0.25 to $1 \%$, $\mathrm{CaCl}_{2}$ extracted $\mathrm{Ni}$ and $\mathrm{Mn}$ increased by 57.73 and $91.33 \%$, respectively.

3.3. Immobilization of Heavy Metals through Biochar. Figures 1(a) and 1(b) show the bioavailability of $\mathrm{Ni}$ and $\mathrm{Mn}$ with the presence of different $\mathrm{ClO}_{4}{ }^{-}$and $\mathrm{BC}$ amendments. The statistical analysis explains that immobilization of $\mathrm{Ni}$ and $\mathrm{Mn}$ is significantly different with $\mathrm{BC}$ amendment rates. However, at higher $\mathrm{ClO}_{4}{ }^{-}$concentrations (i.e., $1 \% \mathrm{ClO}_{4}{ }^{-}$), a significant difference could not be identified between the control and $1 \%$ $\mathrm{BC}$ addition in terms of $\mathrm{Ni}$ and $\mathrm{Mn}$ immobility. Compared to other $\mathrm{BC}$ amendment rates, 5\% BC amendment reduced the bioavailability of $\mathrm{Ni}$ and $\mathrm{Mn}$ greatly. In addition, $\mathrm{BC}$ performed well in the presence of low $\mathrm{ClO}_{4}{ }^{-}$concentrations (i.e., $0.25 \% \mathrm{ClO}_{4}{ }^{-}$) (Figures 2(a) and 2(b)). For instance, 5\% BC- $0.25 \% \mathrm{ClO}_{4}{ }^{-}$combination reduced 91.9 and $92.9 \%$ of $\mathrm{CaCl}_{2}$ extractable of $\mathrm{Ni}$ and $\mathrm{Mn}$, respectively, compared to the control. The final concentration of the $\mathrm{CaCl}_{2}$ extractable $\mathrm{Ni}$ and $\mathrm{Mn}$ in $5 \% \mathrm{BC}-0.25 \% \mathrm{ClO}_{4}{ }^{-}$combination corresponded to the 0.15 and $0.14 \%$ of the total metal concentrations of $\mathrm{Ni}$ and $\mathrm{Mn}$ in serpentine soil, respectively. However, 5\% $\mathrm{BC}-1 \% \mathrm{ClO}_{4}{ }^{-}$combination reduced only 67.6 and $76.5 \%$ of the bioavailability of $\mathrm{Ni}$ and $\mathrm{Mn}$, respectively, compared to the control. In that combination, $\mathrm{CaCl}_{2}$ extractable $\mathrm{Ni}$ and $\mathrm{Mn}$ corresponded to the 1.43 and $5.3 \%$ of the total metal concentrations of $\mathrm{Ni}$ and $\mathrm{Mn}$, respectively. Therefore, it clearly indicates that $\mathrm{pH}$ variations in serpentine soils due to $\mathrm{BC}$ and $\mathrm{ClO}_{4}{ }^{-}$addition (Table 2) show close correlation 


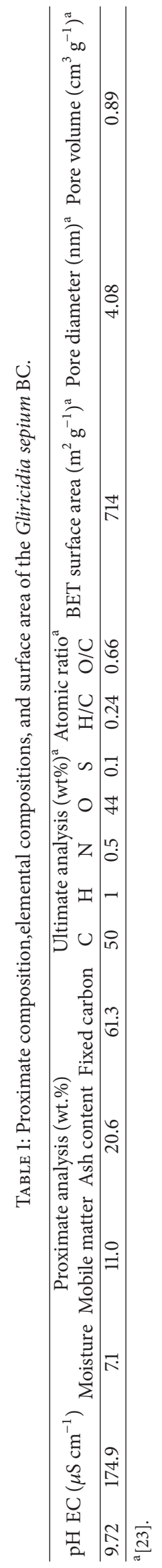




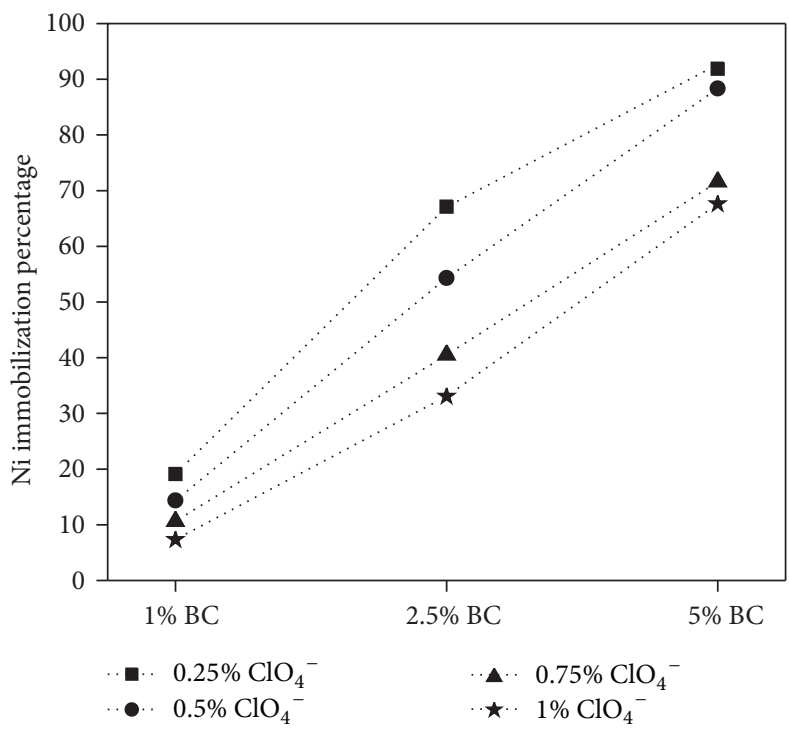

(a)

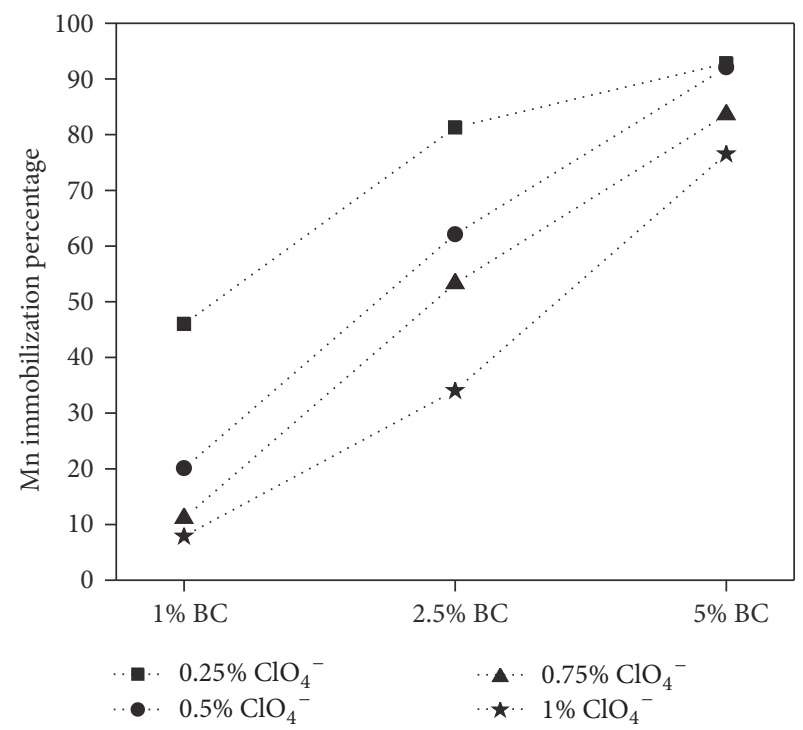

(b)

Figure 2: Influence of $\mathrm{BC}$ addition on $\mathrm{Ni}(\mathrm{a})$ and $\mathrm{Mn}(\mathrm{b})$ immobilization percentage in serpentine soil with each of the $\mathrm{ClO}_{4}{ }^{-}$concentrations.

TABLE 2: Variation of $\mathrm{pH}$ in serpentine soil with different $\mathrm{ClO}_{4}{ }^{-}$and $\mathrm{BC}$ amendment combinations.

\begin{tabular}{lcc}
\hline $\mathrm{ClO}_{4}{ }^{-}$concentration $(\mathrm{w} / \mathrm{w})$ & $\mathrm{BC}$ amendment rate $(\mathrm{w} / \mathrm{w})$ & $\mathrm{pH}$ \\
\hline \multirow{3}{*}{0.25} & 0 & 5.73 \\
& 1 & 5.72 \\
& 2.5 & 5.89 \\
& 5 & 6.09 \\
0.5 & 0 & 5.38 \\
& 1 & 5.44 \\
& 2.5 & 5.59 \\
& 5 & 6.02 \\
0.75 & 0 & 4.90 \\
& 1 & 5.11 \\
& 2.5 & 5.10 \\
& 5 & 5.43 \\
\hline & 0 & 4.49 \\
& 1 & 4.63 \\
& 2.5 & 4.85 \\
& 5 & 5.02 \\
\hline
\end{tabular}

(0.8751 and 0.9150 , resp.) with the bioavailability of $\mathrm{Ni}$ and $\mathrm{Mn}$.

3.4. Possible Mechanisms. Several sorption mechanisms such as organometallic interactions and sorption due to $\pi$ electron donor-acceptor interaction and pore diffusion $[13,36]$ may act as a strong foundation for immobilization of $\mathrm{Ni}$ and $\mathrm{Mn}$ in serpentine soil. The $\mathrm{Ni}$ and $\mathrm{Mn}$, being transition metals, tend to have good coordination affinity to bond with oxygen functional groups (i.e., $\mathrm{COH}, \mathrm{C}=\mathrm{O}$ and $-\mathrm{COOH}$ ) of $\mathrm{BC}$ surface and FTIR spectroscopic analysis revealed that bare $\mathrm{BC}$ contains oxygen functional groups (Figure 3 ). In a study,

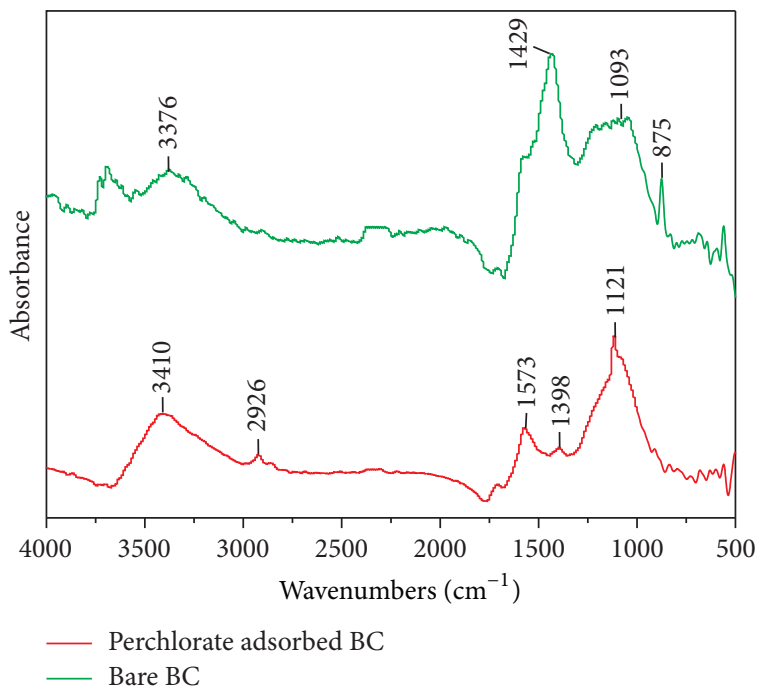

FIGURE 3: FTIR spectrums for bare Gliricidia sepium $\mathrm{BC}$ and $\mathrm{ClO}_{4}{ }^{-}$ adsorbed Gliricidia sepium BC.

Uchimiya et al. [36] concluded that high content of oxygen functional groups is more effective in terms of heavy metals stabilization. The $\mathrm{O}$ atoms of these functional groups can donate their lone pair electrons to electron deficient metal centres and, consequently, this may form organometallic interactions [23]. In addition, the BC produced at high temperatures shows high aromaticity from which metals are sorbed via $\pi$ electron donor-acceptor interactions [23, 37]. More precisely, aromatic carbon consists of double and triple bonds with a pool of $\pi$ electrons; therefore, it leads to forming $\pi$ electron donor-acceptor interactions in order to sorb $\mathrm{Ni}$ and Mn. Moreover, physical properties (i.e., pore diameter, 
TABLE 3: Chemical properties, total metal digestion, and bioavailable concentration for $\mathrm{Ni}$ and $\mathrm{Mn}$ in serpentine soil.

\begin{tabular}{lccccc}
\hline $\mathrm{pH}$ & $\mathrm{EC}\left(\mathrm{dS} \mathrm{m}^{-1}\right)$ & \multicolumn{2}{c}{ Total metal concentration $\left(\mathrm{mg} \mathrm{kg}^{-1}\right)$} & \multicolumn{2}{c}{ Bioavailable metal concentration $\left(\mathrm{mg} \mathrm{kg}^{-1}\right)$} \\
& & $\mathrm{Ni}$ & $\mathrm{Mn}$ & $\mathrm{Ni}$ & $\mathrm{Mn}$ \\
\hline 6.26 & 0.03 & 6,567 & 2,609 & $19.8(0.30)$ \\
\hline
\end{tabular}

Value in parentheses is the percentage of bioavailable metal concentration compared to the total metal concentrations.

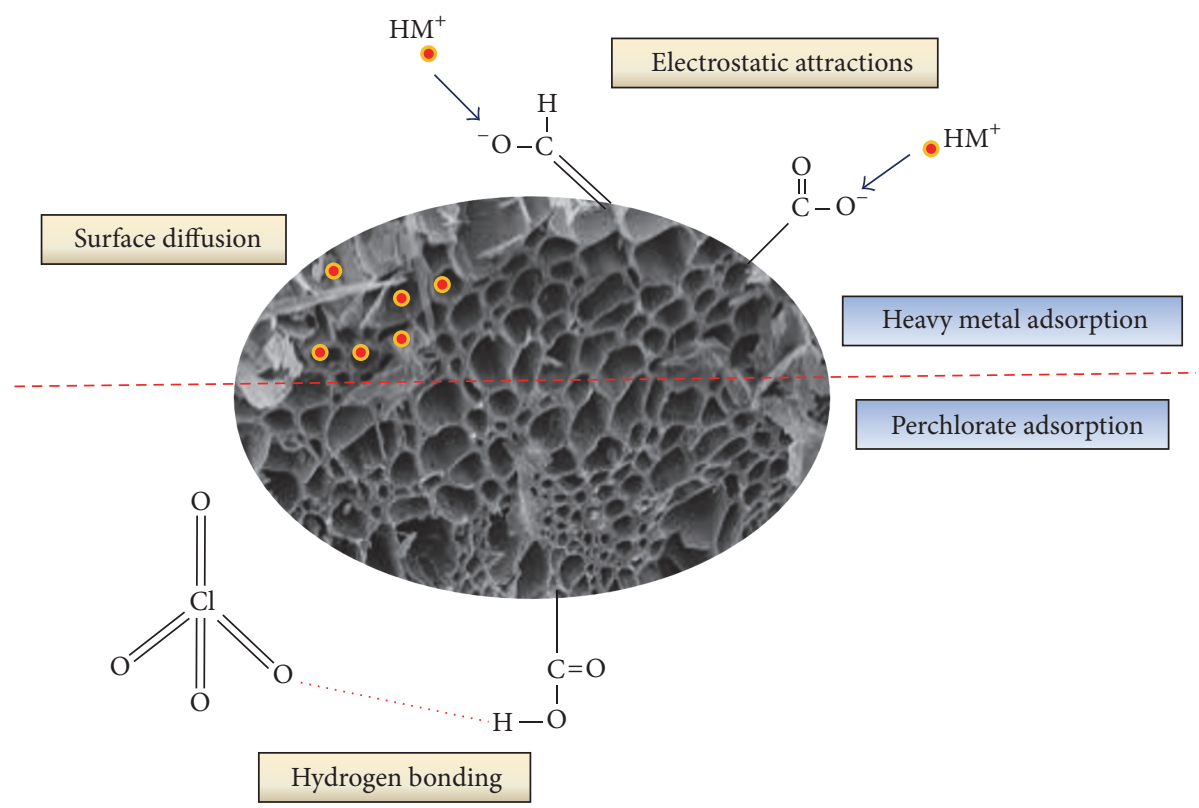

Figure 4: Possible mechanisms for $\mathrm{Ni}$ and $\mathrm{Mn}$ immobilization $\left(\mathrm{HM}^{+}\right.$denoted the respective $\mathrm{Ni}$ and $\mathrm{Mn}$ cations) and $\mathrm{ClO}_{4}{ }^{-}$adsorption onto Gliricidia sepium BC.s

pore volume, and surface area) of BC could govern the diffusion of heavy metals into the BC. However, dissolved organic carbon would block the pores of BCs disturbing heavy metal sorption [38]. Nevertheless, at higher temperatures, BCs are deficient in dissolved organic carbon; as a result, BCs enhance heavy metal immobilization in soil.

As previously mentioned, at higher temperatures, BCs gain low polarity and high aromaticity which stimulate the $\mathrm{ClO}_{4}{ }^{-}$adsorption onto BC. Thus, a further aspect of $\mathrm{Ni}$ and $\mathrm{Mn}$ immobilization is that $\mathrm{BC}$ could adsorb $\mathrm{ClO}_{4}{ }^{-}$as a result; the influence of $\mathrm{ClO}_{4}{ }^{-}$on mobilization $\mathrm{Ni}$ and $\mathrm{Mn}$ may minimize. At higher temperatures, smaller aromatic units in $\mathrm{BC}$ condensed into larger sheets. Aromatic surfaces are rich in $\pi$ electrons which can stimulate the hydrogen bonding or act as acceptors related to most H-bond donors. Therefore, condensed aromatic surface of BC may strengthen hydrogen bond force by facilitating a hydrophobic microenvironment which accommodate weakly hydrated $\mathrm{ClO}_{4}{ }^{-}$and favor $\mathrm{ClO}_{4}{ }^{-}$ binding owing to its $\pi$ system [40].

The FTIR spectra (Figure 3) showed that some peaks were shifted or disappeared and new peaks were also detected between bare and $\mathrm{ClO}_{4}{ }^{-}$adsorbed BC. In bare $\mathrm{BC}$, the peak at $3376 \mathrm{~cm}^{-1}$ could be attributed to phenolic -OH stretching [41]. The peaks at 1429 and $1093 \mathrm{~cm}^{-1}$ were ascribed to $\mathrm{C}=\mathrm{C}$ and $\mathrm{C}-\mathrm{O}-\mathrm{C}$ stretching vibrations [23]. Aromatic $\mathrm{CH}$ outof-plane deformation appeared at $875 \mathrm{~cm}^{-1}$ [42]. In $\mathrm{ClO}_{4}^{-}$ adsorbed BC, the new peak at $2926 \mathrm{~cm}^{-1}$ may be attributed to the oxidative reaction of $\mathrm{ClO}_{4}{ }^{-}$with $\mathrm{BC}$ surface to produce aliphatic $\mathrm{C}-\mathrm{H}$ in addition to producing more oxygenated functional groups in the $\mathrm{BC}$ surface. The band that appeared at the $1573 \mathrm{~cm}^{-1}$ could be assigned to $-\mathrm{COOH}$ and peaks at 1318 and $1121 \mathrm{~cm}^{-1}$ were recognized to be $-\mathrm{C}-\mathrm{O}$ groups $[37,42]$. Therefore, it is evident that, apart from electrostatic attractions, $\mathrm{H}$-bond interactions between weakly hydrated $\mathrm{ClO}_{4}^{-}$and oxygen-containing functional groups such as $\mathrm{COH},-\mathrm{COOH}$ on the aromatic and hydrophobic surface of $\mathrm{BC}$ may play a major role with regard to adsorption of $\mathrm{ClO}_{4}{ }^{-}$. It is evident that far wood derived $\mathrm{BC}$ produced at $500-700^{\circ} \mathrm{C}$ successfully adsorbed $\mathrm{ClO}_{4}{ }^{-}$and the mechanism behind that was the H-bonding interactions [37]. Furthermore, metal oxide present in the $\mathrm{BC}$ may play another adsorptive role in terms of $\mathrm{ClO}_{4}{ }^{-}$adsorption due to the fact that $\mathrm{BC}$ contains high ash content (20.6\%) [43]. Therefore, it could be proposed that $\mathrm{BC}$ immobilizes $\mathrm{Ni}$ and $\mathrm{Mn}$ and adsorbed $\mathrm{ClO}_{4}^{-}$simultaneously (Figure 4). Eventually, the effect of $\mathrm{ClO}_{4}{ }^{-}$on $\mathrm{Ni}$ and Mn immobilization from serpentine soil would be minimized to a greater extent. However, molecular level understanding is required to address the sorption mechanism of the $\mathrm{BC}$ in detail.

\section{Conclusions}

In summary, serpentine soil contained a high concentration of $\mathrm{Ni}$ and $\mathrm{Mn}$ in which 0.30 and $0.25 \%$, respectively, are 
retained as a bioavailable fraction. Addition of $\mathrm{ClO}_{4}{ }^{-}$leads to increasing $\mathrm{CaCl}_{2}$ extractable $\mathrm{Ni}$ and $\mathrm{Mn}$ (4.43 and $22.99 \%$, resp.) in serpentine soil. However, application of Gliricidia sepium BC acts as a strong foundation for immobilizing $\mathrm{Ni}$ and $\mathrm{Mn}$. In addition, it is clear that high rate of $\mathrm{BC}$ amendment could reduce high percentage of $\mathrm{CaCl}_{2}$ extractable $\mathrm{Ni}$ and $\mathrm{Mn}$ and $\mathrm{BC}$ is able to decrease more than $90 \%$ of $\mathrm{CaCl}_{2}$ extractable $\mathrm{Ni}$ and $\mathrm{Mn}$ at low $\mathrm{ClO}_{4}{ }^{-}$concentrations (i.e., $0.25 \% \mathrm{w} / \mathrm{w})$. Taking this into account, it could be concluded that not only immobilization of $\mathrm{Ni}$ and $\mathrm{Mn}$ but also adsorption of $\mathrm{ClO}_{4}^{-}$onto $\mathrm{BC}$ might act simultaneously in order to minimize $\mathrm{CaCl}_{2}$ extractable $\mathrm{Ni}$ and $\mathrm{Mn}$. However, molecular level understanding will be important to explain the sorption mechanism of the Gliricidia sepium BC.

\section{Competing Interests}

The authors declare that they have no competing interests.

\section{References}

[1] P. B. Duncan, R. D. Morrison, and E. Vavricka, "Forensic identification of anthropogenic and naturally occurring sources of perchlorate," Environmental Forensics, vol. 6, no. 2, pp. 205215, 2005.

[2] W. E. Motzer, "Perchlorate: problems, detection, and solutions," Environmental Forensics, vol. 2, no. 4, pp. 301-311, 2001.

[3] L. Ye, H. You, J. Yao, X. Kang, and L. Tang, "Seasonal variation and factors influencing perchlorate in water, snow, soil and corns in Northeastern China," Chemosphere, vol. 90, no. 10, pp. 2493-2498, 2013.

[4] N. Demirkıran and A. Künkül, "Dissolution kinetics of ulexite in perchloric acid solutions," International Journal of Mineral Processing, vol. 83, no. 1-2, pp. 76-80, 2007.

[5] G. Senanayake, J. Childs, B. D. Akerstrom, and D. Pugaev, "Reductive acid leaching of laterite and metal oxides-a review with new data for $\mathrm{Fe}(\mathrm{Ni}, \mathrm{Co}) \mathrm{OOH}$ and a limonitic ore," Hydrometallurgy, vol. 110, no. 1-4, pp. 13-32, 2011.

[6] H. Majima, Y. Awakura, and T. Mishima, "The leaching of hematite in acid solutions," Metallurgical Transactions B, vol. 16, no. 1, pp. 23-30, 1985.

[7] P. Kumarathilaka, C. Oze, S. P. Indraratne, and M. Vithanage, "Perchlorate as an emerging contaminant in soil, water and food," Chemosphere, vol. 150, pp. 667-677, 2016.

[8] A. U. Rajapaksha, M. Vithanage, C. Oze, W. M. A. T. Bandara, and R. Weerasooriya, "Nickel and manganese release in serpentine soil from the Ussangoda Ultramafic Complex, Sri Lanka," Geoderma, vol. 189-190, pp. 1-9, 2012.

[9] D. I. Bannon, J. W. Drexler, G. M. Fent et al., "Evaluation of small arms range soils for metal contamination and lead bioavailability," Environmental Science and Technology, vol. 43, no. 24, pp. 9071-9076, 2009.

[10] F. Monna, C. Petit, J.-P. Gulllaumet et al., "History and environmental impact of mining activity in Celtic Aeduan territory recorded in a peat bog (Morvan, France)," Environmental Science and Technology, vol. 38, no. 3, pp. 665-673, 2004.

[11] C. Adams, E. C. Witt, J. Wang et al., "Chemical quality of depositional sediments and associated soils in New Orleans and the Louisiana peninsula following Hurricane Katrina," Environmental Science \& Technology, vol. 41, no. 10, pp. 3437-3443, 2007.
[12] M. Vithanage, A. U. Rajapaksha, C. Oze, N. Rajakaruna, and C. B. Dissanayake, "Metal release from serpentine soils in Sri Lanka," Environmental Monitoring and Assessment, vol. 186, no. 6, pp. 3415-3429, 2014.

[13] M. Ahmad, A. U. Rajapaksha, J. E. Lim et al., "Biochar as a sorbent for contaminant management in soil and water: a review," Chemosphere, vol. 99, pp. 19-33, 2014.

[14] J. Lehmann and S. Joseph, "Biochar for environmental management: an introduction," in Biochar for Environmental Management: Science and Technology, J. Lehmann and S. Joseph, Eds., pp. 1-9, Earthscan, London, UK, 2009.

[15] S. Shackley, S. Carter, T. Knowles et al., "Sustainable gasification-biochar systems? A case-study of rice-husk gasification in Cambodia, part I: context, chemical properties, environmental and health and safety issues," Energy Policy, vol. 42, pp. 4958, 2012.

[16] M. Vithanage, A. U. Rajapaksha, X. Tang et al., "Sorption and transport of sulfamethazine in agricultural soils amended with invasive-plant-derived biochar," Journal of Environmental Management, vol. 141, pp. 95-103, 2014.

[17] M. Uchimiya, D. I. Bannon, L. H. Wartelle, I. M. Lima, and K. T. Klasson, "Lead retention by broiler litter biochars in small arms range soil: impact of pyrolysis temperature," Journal of Agricultural and Food Chemistry, vol. 60, no. 20, pp. 5035-5044, 2012.

[18] E. Agrafioti, D. Kalderis, and E. Diamadopoulos, "Arsenic and chromium removal from water using biochars derived from rice husk, organic solid wastes and sewage sludge," Journal of Environmental Management, vol. 133, pp. 309-314, 2014.

[19] Y. Han, A. A. Boateng, P. X. Qi, I. M. Lima, and J. Chang, "Heavy metal and phenol adsorptive properties of biochars from pyrolyzed switchgrass and woody biomass in correlation with surface properties," Journal of Environmental Management, vol. 118, pp. 196-204, 2013.

[20] B. B. Kaudal, D. Chen, D. B. Madhavan, A. Downie, and A. Weatherley, "An examination of physical and chemical properties of urban biochar for use as growing media substrate," Biomass and Bioenergy, vol. 84, pp. 49-58, 2016.

[21] V. Hansen, D. Müller-Stöver, L. J. Munkholm, C. Peltre, H. Hauggaard-Nielsen, and L. S. Jensen, "The effect of straw and wood gasification biochar on carbon sequestration, selected soil fertility indicators and functional groups in soil: an incubation study," Geoderma, vol. 269, pp. 99-107, 2016.

[22] C. Liu, H. Wang, X. Tang et al., "Biochar increased water holding capacity but accelerated organic carbon leaching from a sloping farmland soil in China," Environmental Science and Pollution Research, vol. 23, no. 2, pp. 995-1006, 2016.

[23] I. Herath, P. Kumarathilaka, A. Navaratne, N. Rajakaruna, and M. Vithanage, "Immobilization and phytotoxicity reduction of heavy metals in serpentine soil using biochar," Journal of Soils and Sediments, vol. 15, no. 1, pp. 126-138, 2015.

[24] L. Cui, G. Pan, L. Li et al., "Continuous immobilization of cadmium and lead in biochar amended contaminated paddy soil: a five-year field experiment," Ecological Engineering, vol. 93, pp. $1-8,2016$.

[25] T. Bandara, I. Herath, P. Kumarathilaka et al., "Role of woody biochar and fungal-bacterial co-inoculation on enzyme activity and metal immobilization in serpentine soil," Journal of Soils and Sediments, pp. 1-9, 2015.

[26] T. Bandara, I. Herath, P. Kumarathilaka, Z.-Y. Hseu, Y. S. Ok, and M. Vithanage, "Efficacy of woody biomass and biochar 
for alleviating heavy metal bioavailability in serpentine soil," Environmental Geochemistry and Health, pp. 1-11, 2016.

[27] M. Ahmad, Y. S. Ok, A. U. Rajapaksha et al., "Lead and copper immobilization in a shooting range soil using soybean stoverand pine needle-derived biochars: chemical, microbial and spectroscopic assessments," Journal of Hazardous Materials, vol. 301, pp. 179-186, 2016.

[28] L. Beesley, E. Moreno-Jiménez, and J. L. Gomez-Eyles, "Effects of biochar and greenwaste compost amendments on mobility, bioavailability and toxicity of inorganic and organic contaminants in a multi-element polluted soil," Environmental Pollution, vol. 158, no. 6, pp. 2282-2287, 2010.

[29] R. Bian, S. Joseph, L. Cui et al., "A three-year experiment confirms continuous immobilization of cadmium and lead in contaminated paddy field with biochar amendment," Journal of Hazardous Materials, vol. 272, pp. 121-128, 2014.

[30] X. Zhang, H. Wang, L. He et al., "Using biochar for remediation of soils contaminated with heavy metals and organic pollutants," Environmental Science and Pollution Research, vol. 20, no. 12, pp. 8472-8483, 2013.

[31] R. A. Aziz, S. A. Rahim, I. Sahid, and W. M. R. Idris, "Speciation and availability of heavy metals on serpentinized paddy soil and paddy tissue," Procedia-Social and Behavioral Sciences, vol. 195, pp. 1658-1665, 2015.

[32] M. Ahmad, S. S. Lee, A. U. Rajapaksha et al., "Trichloroethylene adsorption by pine needle biochars produced at various pyrolysis temperatures," Bioresource Technology, vol. 143, pp. 615-622, 2013.

[33] X. Cao and W. Harris, "Properties of dairy-manure-derived biochar pertinent to its potential use in remediation," Bioresource Technology, vol. 101, no. 14, pp. 5222-5228, 2010.

[34] P. Kim, A. Johnson, C. W. Edmunds et al., "Surface functionality and carbon structures in lignocellulosic-derived biochars produced by fast pyrolysis," Energy \& Fuels, vol. 25, no. 10, pp. 4693-4703, 2011.

[35] M. Ahmad, Y. Hashimoto, D. H. Moon, S. S. Lee, and Y. S. Ok, "Immobilization of lead in a Korean military shooting range soil using eggshell waste: an integrated mechanistic approach," Journal of Hazardous Materials, vol. 209-210, pp. 392-401, 2012.

[36] M. Uchimiya, S. Chang, and K. T. Klasson, "Screening biochars for heavy metal retention in soil: role of oxygen functional groups," Journal of Hazardous Materials, vol. 190, no. 1-3, pp. 432-441, 2011.

[37] Q. Fang, B. Chen, Y. Lin, and Y. Guan, "Aromatic and hydrophobic surfaces of wood-derived biochar enhance perchlorate adsorption via hydrogen bonding to oxygen-containing organic groups," Environmental Science and Technology, vol. 48, no. 1, pp. 279-288, 2014.

[38] X. Cao, L. Ma, Y. Liang, B. Gao, and W. Harris, "Simultaneous immobilization of lead and atrazine in contaminated soils using dairy-manure biochar," Environmental science \& technology, vol. 45, no. 11, pp. 4884-4889, 2011.

[39] M. Uchimiya, L. H. Wartelle, K. T. Klasson, C. A. Fortier, and I. M. Lima, "Influence of pyrolysis temperature on biochar property and function as a heavy metal sorbent in soil," Journal of Agricultural and Food Chemistry, vol. 59, no. 6, pp. 2501-2510, 2011.

[40] J. Ni, J. J. Pignatello, and B. Xing, "Adsorption of aromatic carboxylate ions to black carbon (Biochar) is accompanied by proton exchange with water," Environmental Science \& Technology, vol. 45, no. 21, pp. 9240-9248, 2011.
[41] R.-K. Xu, S.-C. Xiao, J.-H. Yuan, and A.-Z. Zhao, "Adsorption of methyl violet from aqueous solutions by the biochars derived from crop residues," Bioresource Technology, vol. 102, no. 22, pp. 10293-10298, 2011.

[42] S. S. Mayakaduwa, P. Kumarathilaka, I. Herath et al., "Equilibrium and kinetic mechanisms of woody biochar on aqueous glyphosate removal," Chemosphere, vol. 144, pp. 2516-2521, 2016.

[43] D. Peak, "Adsorption mechanisms of selenium oxyanions at the aluminum oxide/water interface," Journal of Colloid and Interface Science, vol. 303, no. 2, pp. 337-345, 2006. 

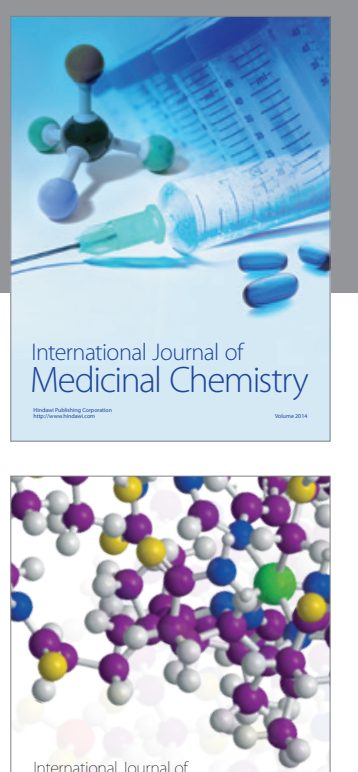

Carbohydrate Chemistry

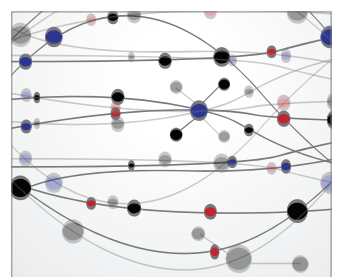

The Scientific World Journal
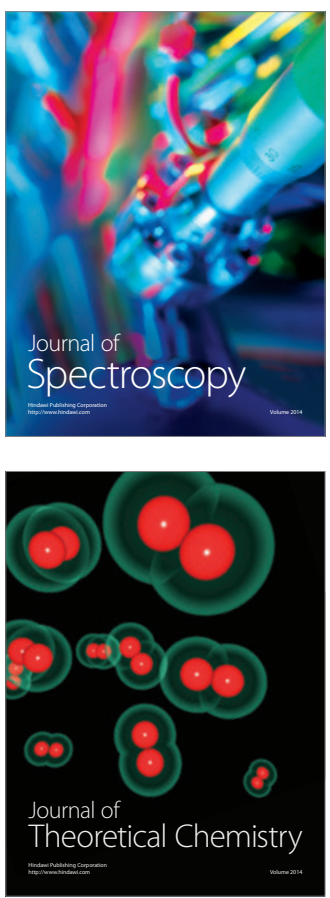
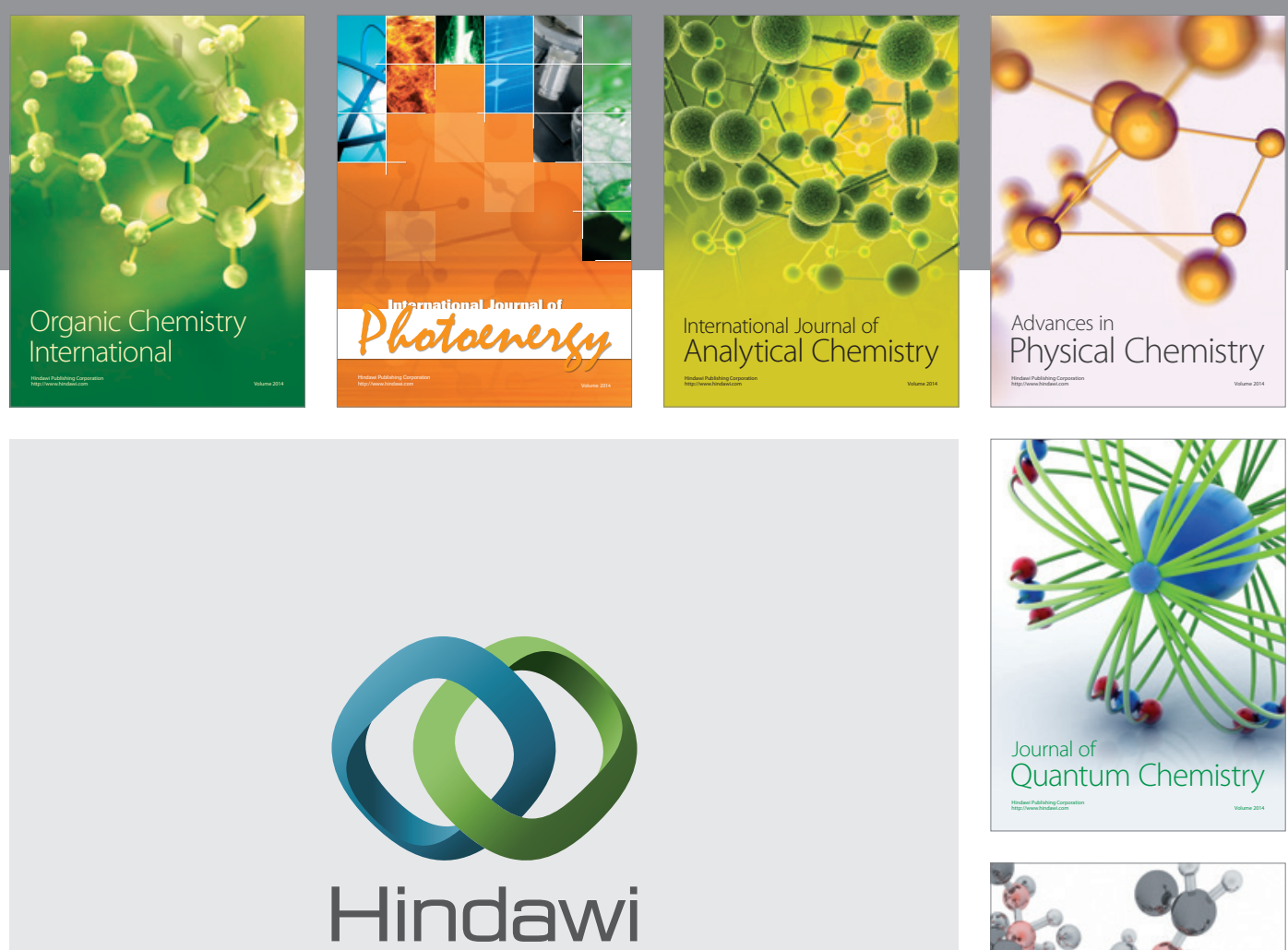

Submit your manuscripts at

https://www.hindawi.com

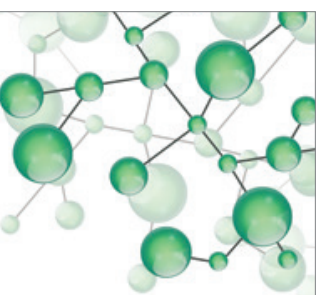

International Journal of

Inorganic Chemistry
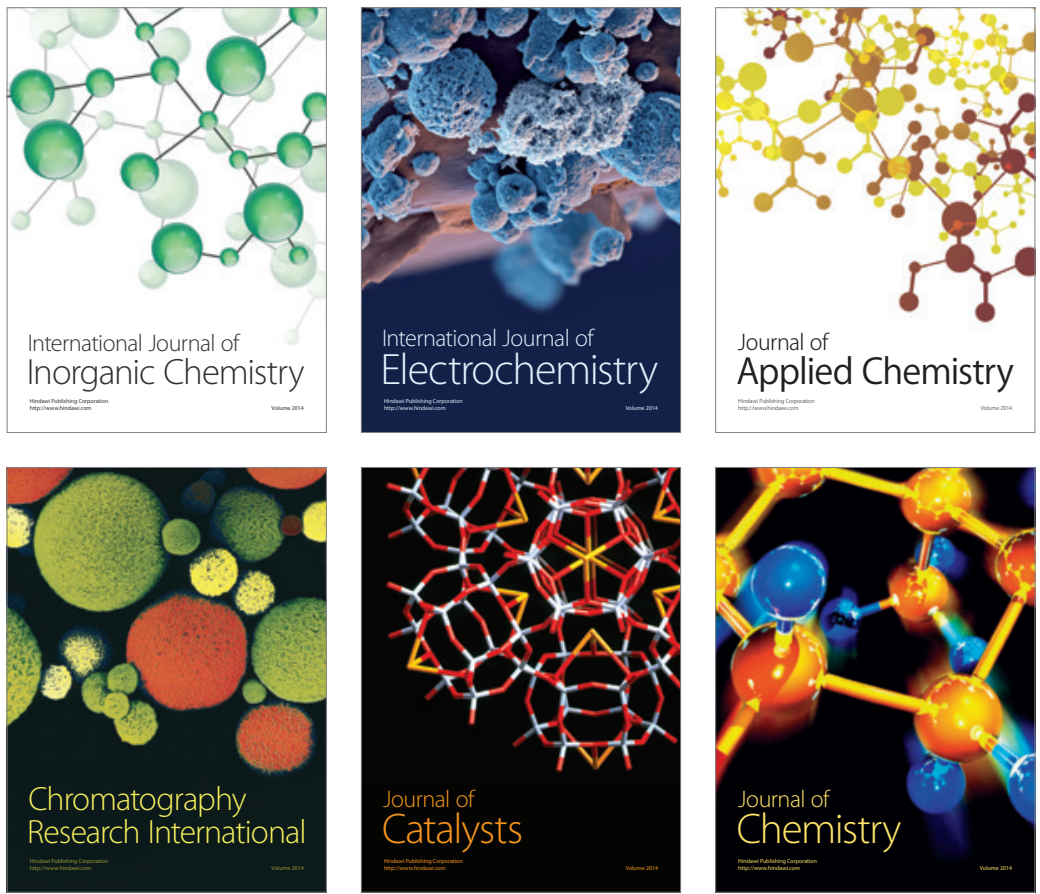

Journal of

Applied Chemistry
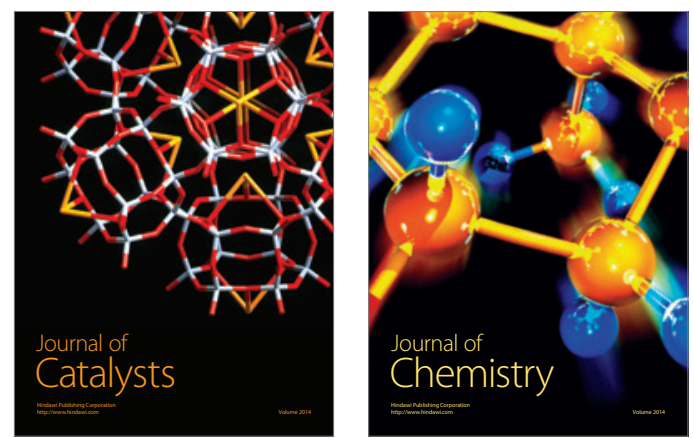
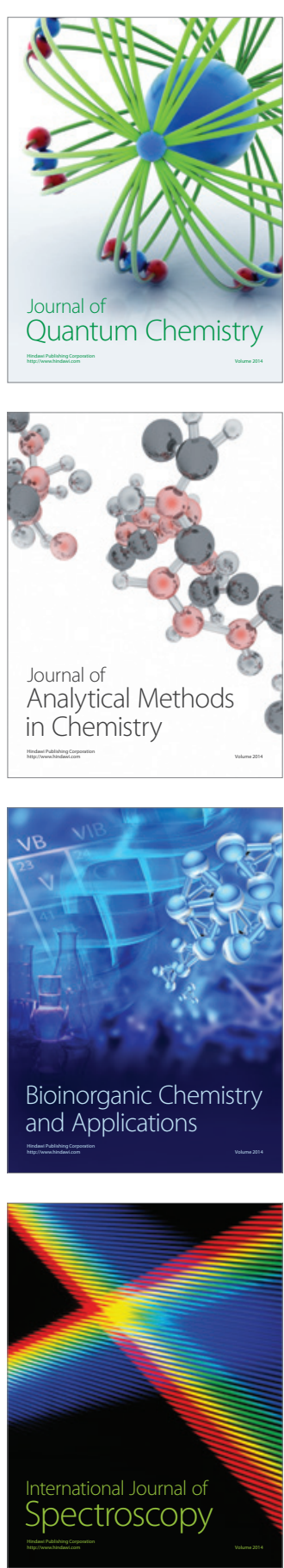